\title{
SETP: A New Powerful Tool for Improving Problem Solving, Decision Making and Creativity in Teenagers.
}

\author{
Dr. Arvinder Singh ${ }^{1}$, Dr. Ajay K. Chaudhary ${ }^{2}$
}

\section{ABSTRACT:}

Our decisions decide our destiny. Problem solving, decision-making, analytical reasoning and creativity are important abilities not only for studies but also for every sphere of life. SETP (Seven Effective Thinking Patterns) tool developed by Dr. Arvinder Singh was applied on teenagers to study the effect on their cognitive abilities. The study was done on 50 convent school students. Important parameters like Innovative Thoughts, Decisive Factors, Pros- Cons Analysis and Broader Perspectives were studied on the scale of 1 to 5. Scoring was done for Pretraining and Post-training sessions. For innovative thoughts pre-training score was 2.10 \pm 0.678 , while for post training it was $3.34 \pm 0.717$. Decisive factor's pre-training score was $1.68 \pm 0.653$, while for post training it was 3.52 \pm 0.735 . Pros-cons analysis pre-training score was $1.66 \pm 0.557$ and post training score was 3.32 \pm 0.768 . Broader perspective pre-training score was $1.86 \pm 0.700$, while for post training it was 3.52 \pm 0.931 .For language pre-training score was $2.70 \pm 0.763$, while for post training it was $2.76 \pm 0.847$. For expression pre-training score was $2.68 \pm 0.768$ and for post training it was $2.88 \pm 1.256$. The above findings suggest that SETP tool was effective and showed significant improvement in 4 out of 6 parameters. The tool was not effective for language and expression parameters. Important point is that by SETP tool, we were able to enhance the cognitive abilities of school going children, which will make solid foundation for their future.

Keywords: SETP, Seven Effective Thinking Patterns, Problem Solving, Decision Making,

Creativity.

Our decisions decide our fate. Taking effective decision and solving problems are fundamental for successful enriched life. Although management institutions teach decision-making and problem solving, but the tools available are somewhat effective on adult population only. In current era where Internet, information overload and multiple career opportunities are available, the teens many a times find themselves confused and lost.

${ }^{1} \mathrm{CEO} \& \mathrm{CMD}$, Rahat Hospital, Udaipur

${ }^{2}$ Senior Lecturer, Department of Psychology, Government Meera Girls' College, Udaipur

(C) 2015 I A Singh, A Chaudhary; licensee IJIP. This is an Open Access Research distributed under the terms of the Creative Commons Attribution License (http://creativecommons.org/licenses/by/2.0), which permits unrestricted use, distribution, and reproduction in any Medium, provided the original work is properly cited. 
The SETP tool, which is very effective on adults, is applied in this study for teenagers with modification and suitability for teens to study the effect on their abilities of Problem Solving, Decision Making and Creativity. SETP is abbreviation for Seven Effective Thinking Patterns is the tool designed and developed by Dr. Arvinder Singhwho is postgraduate in medical science and trained in management from IIM and Oxford. The tool is designed by amalgamating the principles of Medical Science and Human Psychology. It is based on various researches that mind has different faculties to think and while thinking the optimum use of thinking power can be done by focusing on one thinking faculty at a time. Most of the people are unable to do this and they think by partially igniting all faculties of mind simultaneously leading to confused state of mind and/or ineffective decision. The confused state of mind lead to stress and inhibits the creativity at the time of problem solving when actually it is needed the most. The SETP tool teaches to harness the maximum potential of mind by focusing on different thinking faculties individually and finally integrating them synergistically to achieve optimum and effective result. The Seven Effective Thinking Patterns are:

1. Metacognitive Thinking Pattern

2. Objective Thinking Pattern

3. Constructive Thinking Pattern

4. Critical Thinking Pattern

5. Creative Thinking Pattern

6. Emotive Thinking Pattern

7. Radiant Thinking Pattern

The "SETP" teaches how to use these patterns and customize sequential order of employing the thinking pattern depending on the varying situation

\section{REVIEW OF LITERATURE:}

Various researches have been done to improve the potential of mind for effective decisionmaking and problem solving. Russell Ackoff (1978), Author of 'The Art of Problem Solving,' makes a strong point when he says "The effort to what we do not want is reactive, retrospectively oriented problem solving. The effort to obtain what we want is proactive, prospectively oriented problem solving."Proctor (1989) mentioned that we should use metaphors for solving the problems but he also indicated that metaphors should not be too close to the problem at hand, else familiar metaphors will not be enough to gain useful ideas or insights. Dr. Edward de Bono (2000)employed Six Thinking Hats technique by coding different thinking modes.O'Connor et al (2000) insisted on the need of reframing the problem for finding hidden solutions that 
otherwise may be difficult to find.John Adair (2007) emphasized that thinking is not a tidy process but it should be done with a sense of order.

\section{MATERIAL AND METHODS:}

The sample comprises of 50 adolescents randomly selected from convent schools of Udaipur district of Rajasthan. The age of sample ranges between 16-18 years and were boys. They all belonged to middle socio-economic status and were average on academic achievements. They were given topic of " Junk Foods should be banned in India “. Students were asked to write essay of around 300 words in one hour. The answer sheets were labeled my unique number given to students. Then students were trained by SETP tool without giving any reference to the essay or art of writing essay. After training program they were asked to write essay on the same topic andthe answer sheets were again labeled by unique number.

Three independent evaluators on prescribed parameters evaluated answer sheets and given scores of all three were averaged. The evaluators were kept blind about any tool applied and were not told that they are evaluating the same student twice. In short evaluators evaluated 100 copies unaware of SETP tool application. The selected parameters for evaluation of essay were:

- Innovative Thoughts

- Decisive Factors

- Pros- Cons Analysis

- Expression

- Language

- Broader Perspectives.

The evaluation was done on a scale of 1 to 5 .

Results were analyzed by the Paired ' $t$ ' test was used for comparing pre and post test scores. All the calculations were done through SPSS Version 21.0. 
SETP: A New Powerful Tool for Improving Problem Solving, Decision Making and Creativity in Teenagers

\section{RESULTS:}

Table and chart below depicts the scores of all 6 evaluated parameters on a scale of 1 to

5 .

Table 1

Pre and post analysis of desired parameters after application of SETP tool on scale of 1 to 5

\begin{tabular}{|c|c|c|c|c|c|c|c|c|}
\hline & & Mean & $\mathrm{N}$ & \begin{tabular}{|l} 
Std. \\
Deviation
\end{tabular} & \begin{tabular}{|l} 
Std. \\
Error \\
Mean
\end{tabular} & $\begin{array}{l}\text { Mean } \\
\text { Difference }\end{array}$ & $\mathrm{t}$ & $\mathrm{P}$ value \\
\hline \multirow{2}{*}{$\begin{array}{l}\text { Innovative } \\
\text { Thoughts }\end{array}$} & Pre-test & 2.10 & 50 & 0.678 & 0.096 & \multirow[t]{2}{*}{1.240} & \multirow[t]{2}{*}{18.406} & \multirow[t]{2}{*}{.000} \\
\hline & Post-test & 3.34 & 50 & 0.717 & 0.101 & & & \\
\hline \multirow{2}{*}{$\begin{array}{l}\text { Decisive } \\
\text { Factors }\end{array}$} & Pre-test & 1.68 & 50 & 0.653 & 0.092 & \multirow[t]{2}{*}{1.840} & \multirow[t]{2}{*}{27.817} & \multirow[t]{2}{*}{.000} \\
\hline & Post-test & 3.52 & 50 & 0.735 & 0.104 & & & \\
\hline \multirow{2}{*}{$\begin{array}{l}\text { Pros-Cons } \\
\text { Analysis }\end{array}$} & Pre-test & 1.66 & 50 & 0.557 & 0.079 & \multirow[t]{2}{*}{1.660} & \multirow[t]{2}{*}{22.598} & \multirow[t]{2}{*}{.000} \\
\hline & Post-test & 3.32 & 50 & 0.768 & 0.109 & & & \\
\hline \multirow[t]{2}{*}{ Expression } & Pre-test & 2.68 & 50 & 0.768 & 0.109 & \multirow[t]{2}{*}{0.200} & \multirow[t]{2}{*}{01.871} & \multirow[t]{2}{*}{.067} \\
\hline & Post-test & 2.88 & 50 & 1.256 & 0.178 & & & \\
\hline \multirow[t]{2}{*}{ Language } & Pre-test & 2.70 & 50 & 0.763 & 0.108 & \multirow[t]{2}{*}{0.060} & \multirow[t]{2}{*}{01.769} & \multirow[t]{2}{*}{.083} \\
\hline & Post-test & 2.76 & 50 & 0.847 & 0.120 & & & \\
\hline \multirow{2}{*}{$\begin{array}{l}\text { Broader } \\
\text { Perspective }\end{array}$} & Pre-test & 1.86 & 50 & 0.700 & 0.099 & \multirow[t]{2}{*}{1.660} & \multirow[t]{2}{*}{17.051} & \multirow[t]{2}{*}{.000} \\
\hline & Post-test & 3.52 & 50 & 0.931 & 0.132 & & & \\
\hline \multirow[t]{2}{*}{ Total } & Pre-test & 12.68 & 50 & 1.994 & 0.282 & \multirow[t]{2}{*}{6.800} & \multirow[t]{2}{*}{31.524} & \multirow[t]{2}{*}{.000} \\
\hline & Post-test & 19.48 & 50 & 2.332 & 0.330 & & & \\
\hline
\end{tabular}

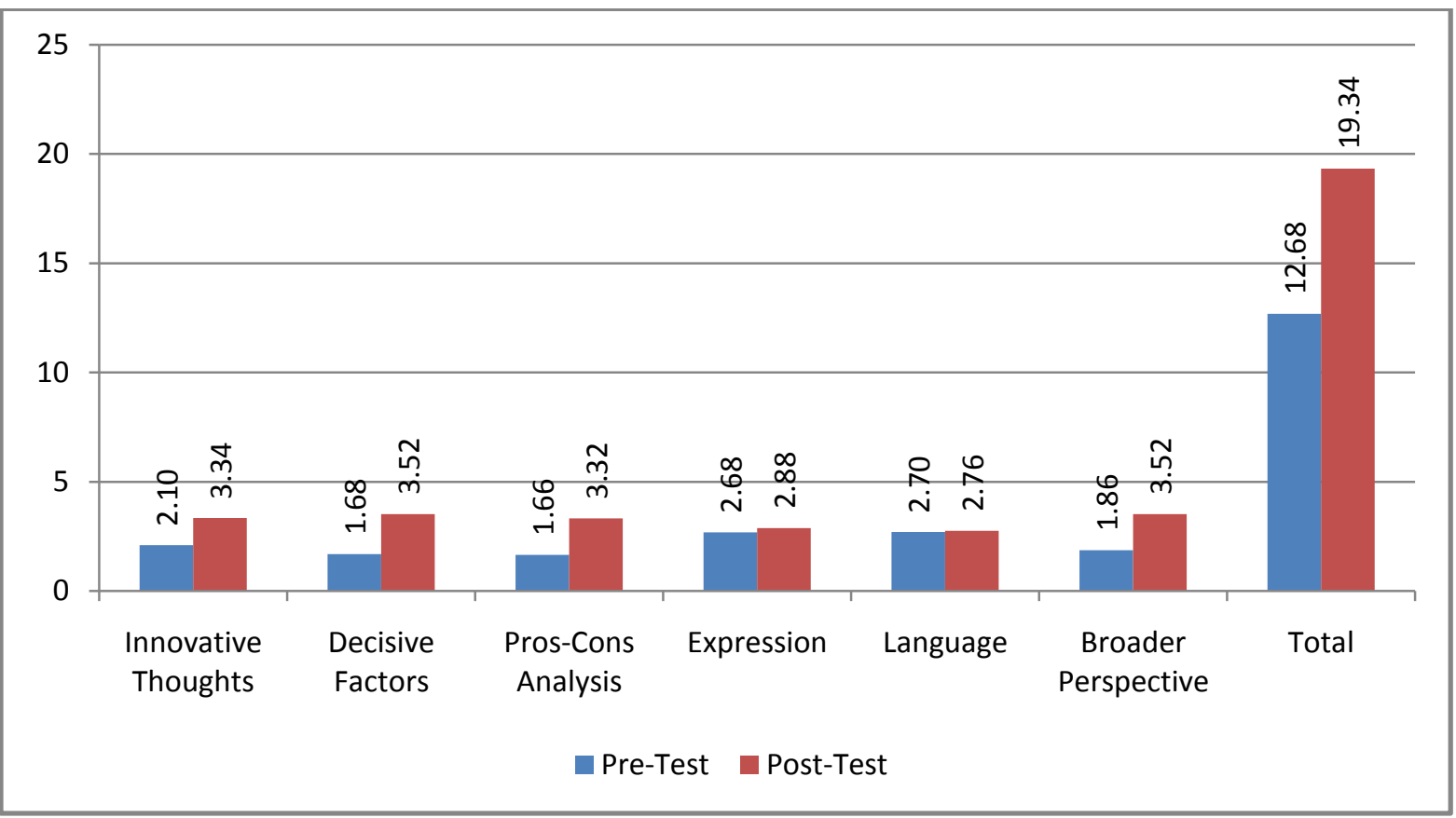




\section{SETP: A New Powerful Tool for Improving Problem Solving, Decision Making and Creativity in Teenagers}

\section{DISCUSSION:}

The above table and graph indicate that the mean and standard deviation score for innovative thoughts during pre-training situation was found to be $2.10 \pm 0.678$, while for post training situation it was found to be $3.34 \pm 0.717$. The mean difference was found to be 1.240 and the ' $t$ ' score was found to be 18.406 which is significant at 0.01 level $(\mathrm{p}<0.01)$. It infers that there is significant increase in scores of innovative thoughts due to intervention of SETP.

The results show that the mean and standard deviation score for decisive factors during pretraining situation was found to be $1.68 \pm 0.653$, while for post training situation it was found to be $3.52 \pm 0.735$. The mean difference was found to be 1.840 and the ' $t$ ' score was found to be 27.817, which is significant at 0.01 level $(\mathrm{p}<0.01)$. It deduces that there is significant increase in scores of decisive factors due to contribution of SETP.

The evaluation of answer sheets indicate that the mean and standard deviation score for proscons analysis during pre-training situation was found to be $1.66 \pm 0.557$, while for post training situation it was found to be $3.32 \pm 0.768$. The mean difference was found to be 1.660 and the ' $t$ ' score was found to be 22.598, which is significant at 0.01 level $(\mathrm{p}<0.01)$. It concludes that there is significant increase in scores of pros-cons analysis due to involvement of SETP.

The above table and graph views that the mean and standard deviation score for expression during pre-training situation was found to be $2.68 \pm 0.768$, while for post trainingsituation it was found to be $2.88 \pm 1.256$. The mean difference was found to be 0.200 and the ' $t$ ' score was found to be 1.871 , which is insignificant $(\mathrm{p}>0.05)$. It determines that there are no significant changes in scores of expression due to involvement of SETP.

The results reflect that the mean and standard deviation score for language during pre-training situation was found to be $2.70 \pm 0.763$, while for post training situation it was found to be $2.76 \pm 0.847$. The mean difference was found to be 0.060 and the ' $t$ ' score was found to be 1.769 , which is insignificant $(\mathrm{p}>0.05)$. It accomplishes that there are no significant changes in scores of language due to involvement of SETP.

The above table and graph produce that the mean and standard deviation score for broader perspective during pre-training situation was found to be $1.86 \pm 0.700$, while for post training situation it was found to be $3.52 \pm 0.931$. The mean difference was found to be 1.660 and the ' $t$ ' score was found to be 17.051, which is significant at 0.01 level $(\mathrm{p}<0.01)$. It achieves that there is significant increase in scores of broader perspective due to involvement of SETP. 
The results remark that the mean and standard deviation score for total scores during pre-training situation was found to be $12.68 \pm 1.994$, while for post training situation it was found to be 19.48 \pm 2.332 . The mean difference was found to be 6.800 and the ' $t$ ' score was found to be 31.524 , which is significant at 0.01 level $(\mathrm{p}<0.01)$. It surmises that there is significant increase in total scores due to involvement of SETP.

\section{CONCLUSION:}

It is concluded that SETP is very effective tools for improving the parameters of innovative thoughts, decisive factors, Pros-Cons analysis and broader perspectives. These qualities are important and essential for problem solving and decision-making. At the same time improvement in innovative thoughts is helpful to increase the creativity level. The application of these tools to school and college students may change their lives for better because in this information rich competitive environment the ability to take effective decisions and creative solution of problems is essential. The main point here is that by SETP tool, we are enhancing the abilities ofschool going children, which will make solid foundation for their future.

\section{REFERENCES:}

1. de Bono Edward (2000), Six Thinking Hats, $2^{\text {nd }}$ Edition, Penguin 8 wheeler.

2. O'Connor, Joseph and Seymour, John (2000), Training with NLP: Skills for Trainers, Managers and Communicators, Thorsons.

3. Adair, John (2007), Decision Making and Problem Solving Strategies, The Sunday Times, Kogan Page.

4. Ackoff, Russell L. (1978), The Art of Problem Solving, John Wiley and Sons.

5. Proctor R.A. (1989) 'The Use of Metaphor to Aid the Process of Creative Problem Solving', Personnel Reviews, 18, 4.

6. Hurson, Tim (2008), Think Better: An Innovator's Guide to Productive Thinking, McGraw-Hill.

7. Carson, Shelley (2010), Your Creative Brain: Seven Steps to Maximize Imagination, Productivity and Innovation in Your Life, Jossey Bass.

8. Byrne, Rhonda (2006), The Secret, Atria Books/Beyond Words.

9. Proctor, Tony (1999) Creative Problem Solving For Managers, Routtedge.

10. Gelb, Michael (2000), How to Think Like Leonardo da Vinci: Seven Steps to Genius Every Day, Dell. 